\title{
Trends in Development of Public Outdoor Space, an Example of Copenhagen
}

\author{
Una İle, Latvija Universoty of Agriculture
}

\begin{abstract}
The research is based on the previous studies of the author on landscape quality and modern development trends based on the knowledge of theories that have emerged in recent years in the Scandinavian countries. Diverse compositional solutions for public outdoor space were observed in both Norway and Sweden that determine and highlight modern and urban open space easily accessible for each user. The article describes current trends, highlights ways how to plan and implement public outdoor space revealing the experience of the city of Copenhagen and Superkilen Park which was officially opened in 2012.
\end{abstract}

Keywords: public outdoor space, development trends, improvement

\section{Introduction}

Jan Gehl, a Danish architect and city designer, claims that three basic directions may be distinguished in functional and aesthetic design of public outdoor space: the necessary activities, intended activities and social activities. Recreation function in this division corresponds to the second category where its activities directly depend on suitable outdoor conditions - "if there is a wish.... and if the time and place allows" [1]. What is the experience of other cities? It is worthwhile to study the experience of Nordic countries which are located in the same climate zone as Latvia and in similar coastal conditions [2]. The Nordic countries long ago worked out the policy supporting a successful dialogue between the community and city planning process. Not only the big cities (Helsinki, Oslo, Stockholm), but also the small ones (Tampere, Tapiola, Malme) could be mentioned as urban areas where city planners stress the significance of the involvement of society in the planning process [3].

The main task of the municipal plan of Copenhagen in 1993 was to create a comprehensive development in the integrated city where different urban activities are combined in unity if it possible from the point of view of city development planning, environment and transport infrastructure planning principles. In the time period from 1975-1990 the number of Copenhagen population decreased by 58,000 people while the number of residents in other parts of the country rose. Copenhagen city planners considered that one of the reasons could be unpleasant living conditions in the capital city. Consequently, in 1993 the main task of the municipal plan of Copenhagen was to provide high quality opportunities for apartment buildings by setting the priority for designing of attractive areas near the water bodies accessible to public services and public transport [4]. Currently, European policy of urban environment mostly follows tendencies of urban development instead of setting the guidelines for city development. There is a big gap between the cities of Western Europe and those of post-socialism countries which have to overcome transition processes in various areas of life [5]. Kevin Lynch states that it is possible to design buildings in the way that people may fully get accustomed to external environment, navigate and learn roads and routes. He write that a successful environment landscape offers its user an important feeling of emotional safety [6]. Building intensity should not be implemented by decreasing or restricting functional diversity of the public open space. Each users' group of any open space has its specific needs which should be respected by creating both passive or active recreation zones and entertainment places for people of different ages, which is illustrated in Figures 1, 2, 3. A special attention should be paid to the landscape quality in the public open space improvement plans, which is a factor increasing a recreation level when purposefully implemented [1]. Therefore the aim of the research was to acquire new knowledge on trends of public outdoor space development on the example of Superkilen Park in Copenhagen and shed a new light on planning approaches in the field of landscape architecture.

\section{Materials and Methods}

The methodological and informative basis refers to current analytical review of open spaces in the central part of Copenhagen which were visited and analysed in April, 2017. Within the framework of the research the public outdoor space in the centre of Copenhagen was investigated and analysed on the basis of current trends in the design and planning approaches, because implemented design solutions of public outdoor spaces of Copenhagen may be of interest to landscape architecture professionals at the national level of Latvia. The literature review included the study of publications and electronic resources depicting information of improvement of urban spaces in the 21 st century. The induction method was used in the research which was based on the analysis of visited areas and obtained photo 


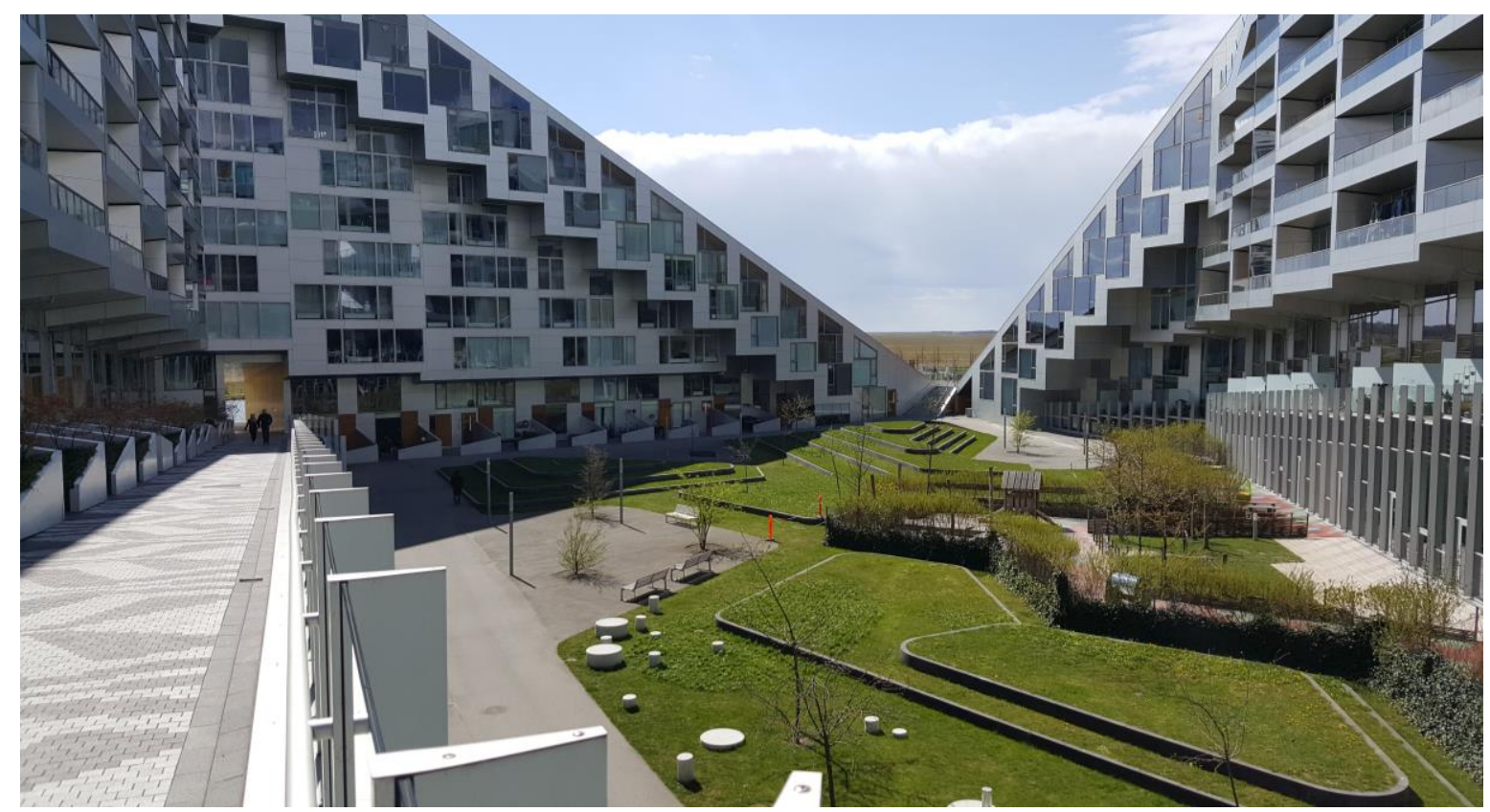

Fig. 1. Asger Jorns Allé: a magnificent shape and solution of 8House residential buildings [Source: photo by the author, 2017]

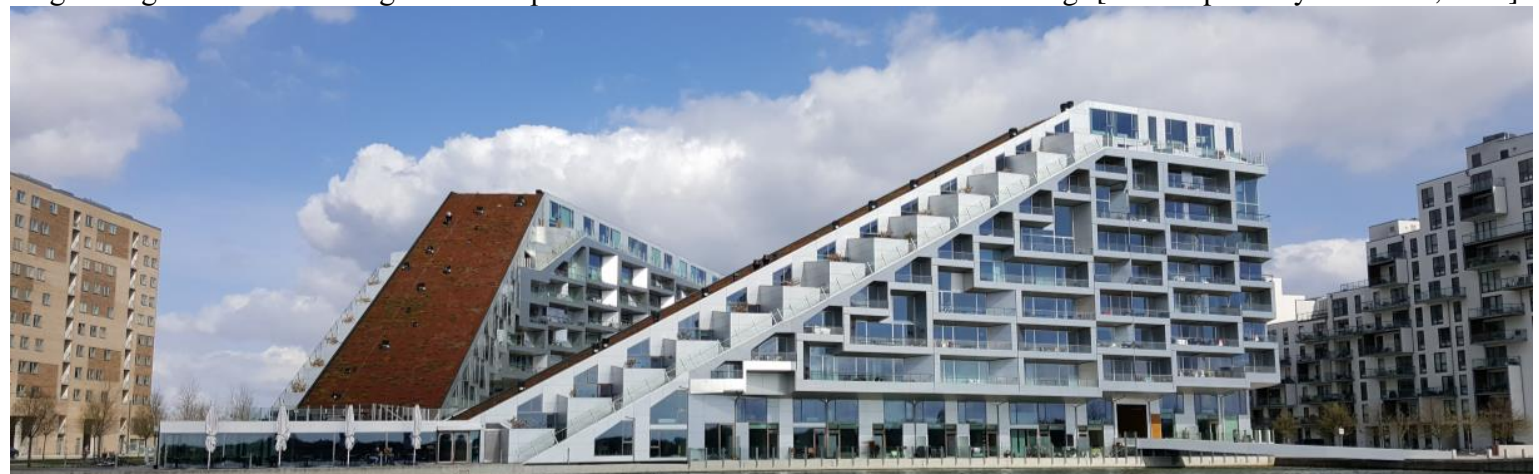

Fig. 2. Inner courtyard of 8House residential houses [Source: photo by the author, 2017]

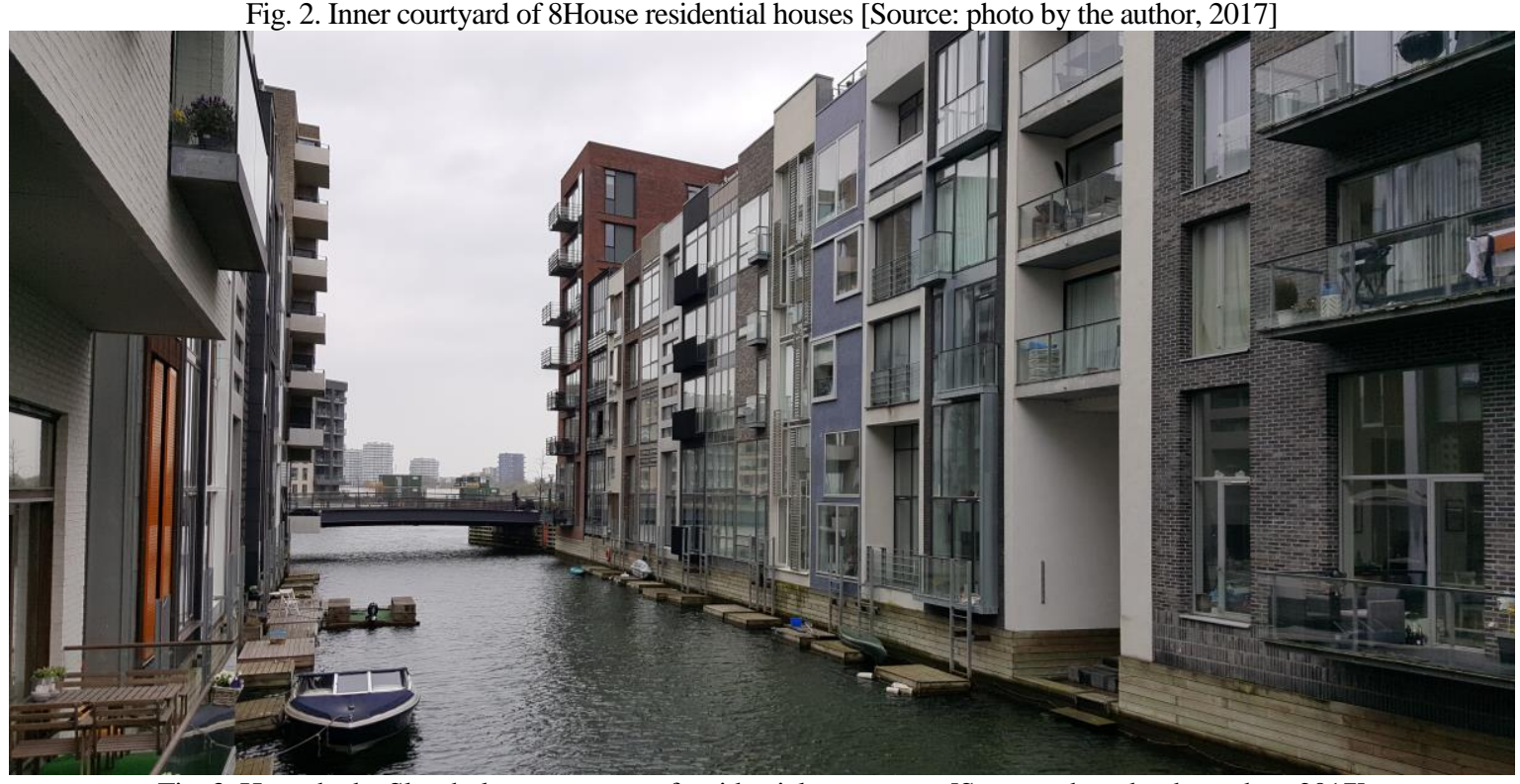

Fig. 3. Havenbadet Sluseholm - new area of residential apartments [Source: photo by the author, 2017] 
fixations in Copenhagen. The monographic or descriptive method was used in the research for the analysis of the results based on the theoretical assumptions and the previous studies of the author on public outdoor planning solutions and composition elements - shapes, proportions, colour, contrasts, nuances, rhythm etc. which have been published in the scientific articles: Île U., (2012), Compositional planning of residential outdoor space in courtyards. Scientific Journal of Riga Technical University, Architecture and Urban Planning. Riga, RTU, pp. 6-11; Île U., (2011), Landscape composition development stages in multi-storey residential areas of the Baltic sea region. Science Future of Lithuania. Vilnius, Vilnius Technika, pp.16-22; Île U., (2011), The aesthetic quality of landscape composition in the multi-storey residential areas. Scientific Journal of Riga Technical University, Architecture and Urban Planning. Riga, RTU, pp. 108-114.

\section{Results and Discussion}

Jan Gehl, a Danish architect and city planner, has contributed significantly to functional and aesthetic design and improvements of the public outdoor space regarding navigation of vehicles and pedestrians in cities [7]. Kevin Lynch, an American city planner, is known for his empirical investigations on city planning. He analysed how individuals perceived and moved in a city, how urban environment influenced children and how to use human perception of physical shape of cities and regions as the conceptual basis for good city design. Lynch claimed that elements in cities may be divided into five groups: paths, edges, districts, nodes and landmarks [8]. Consequently, theoretically the public outdoor space in Copenhagen with its diverse compositional solutions, ability to navigate in specific areas proved to be safe and comfortable urban environment for its users. The public outdoor areas in the central part of Copenhagen were visited and urban improvement projects were recorded by the author; Superkilen Park was selected for the closer investigation. The park is divided into three parts: The Red Square, The Black Market, The Green Park; these visually different designs create environmental contrasts, see Figure 4. The space perception and composition are two different concept groups, which up to now do not have corresponding mutually connected problems, research and perceptions.

On the one hand, an impression of human psychophysiology is created, but, on the other hand, a variety of objects with compositional elements - a shape, proportions, colour, rhythm, nuances etc. prevail $[8 ; 9 ; 10]$. These compositional elements of the analysed Superkilen Park highlight current trends and represent a distinctively different visual overview in the urban environment.

Superkilen Park is an informationally saturated park territory in the urban environment, reflecting cultural diversity encountered in Copenhagen city. It is a collection of famous objects or their copies from 60 countries. The main aim of the park is to reflect the ethnic diversity of Copenhagen, the elements used in the park symbolizes different nationalities from all over the world. Objects in the park have been specially imported from a certain country or copied from original designs. A walk through the park resembles a global walk ranging from neon signs from the USA, traditional swing from Iraq, bench design from Brazil, Spanish statue of a bull, fountain from Morocco, boxing rink from Thailand, rubbish bins of English design and soil from Palestine. Each object is accompanied by a small plate describing the object, what it is and where it is from [11].

Superkilen Park is the result of collaboration of local residents because the design reflects different nationalities living in Copenhagen. The idea was to create a publicly accessible area when everyone feels at home, and it is not important where has a user of a specific place come from. The total length of the park is $750 \mathrm{~m}$, it is located in Nørrebro district to the north of Copenhagen centre which ethnically is one of the diverse regions in the city.

It was a challenge for the authors of the park to make the public outdoor space attractive to any user and to be applicable in diverse contexts, see Figures 5, 6, 7. The authors of the Superkilen Park consider that they have achieved a balance. They are artists from Superflex, architects from Bjarke Ingels Group (BIG) and landscape architects from Topotek1. The idea of creation of this park belong to the city of Copenhagen which was supported by Realdania which is a private Danish organisation supporting philanthropic projects of architecture and city planning [11].

Officially Superkilen Park was opened in June of 2012, its total are is $30,000 \mathrm{~m} 2$; it is possible to use bicycle paths to get to other districts of the city; there are various playgrounds and sport grounds, recreation places to spend time in different culture activities, picnic places with grill elements, see Figures 8 and 9. The parts of Superkilen Park: the Read Square's main functions are to create an impression of recreation and modern life style. Its stimulating colours - bright red, orange, pink - enhance the desire to work actively and generate the flow of energy, but an expressive colourful and attractive character is played through colour contrasts, see Figures 10 and 11. 


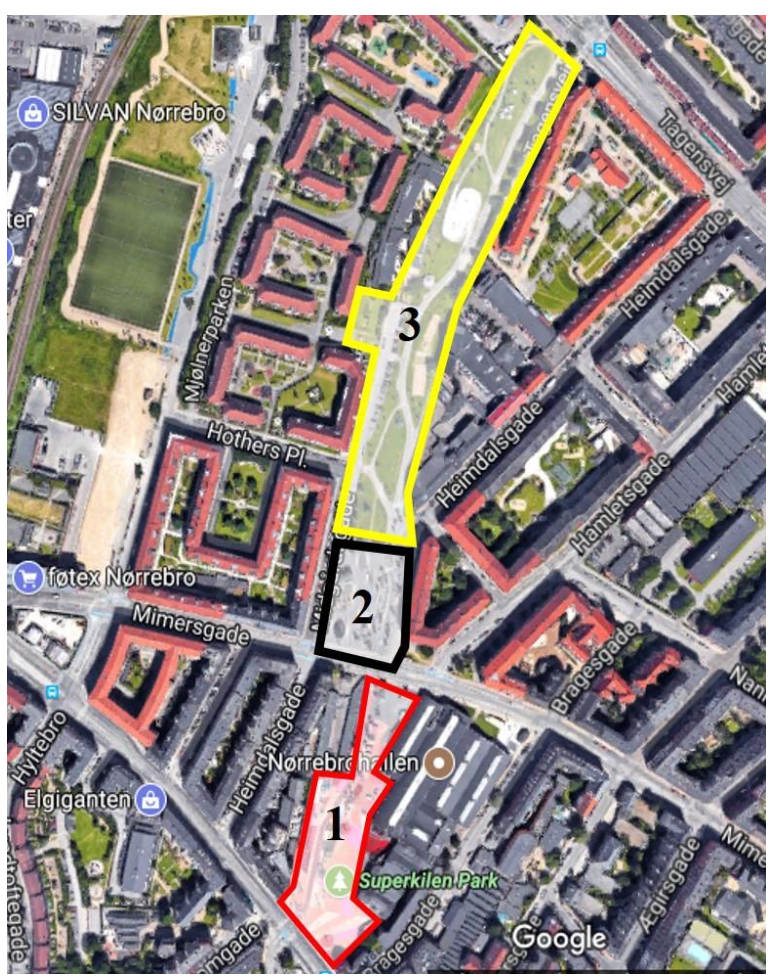

Fig. 4. The territory of Superkilen park: Red Square, Black Market and Green park [Source: Scheme created by the author, using aerophoto map from www.google.lv/maps, 2017]; 1 - the territory of the Red Square; 2 - the territory of the Black Market; 3- the territory of the Green Park

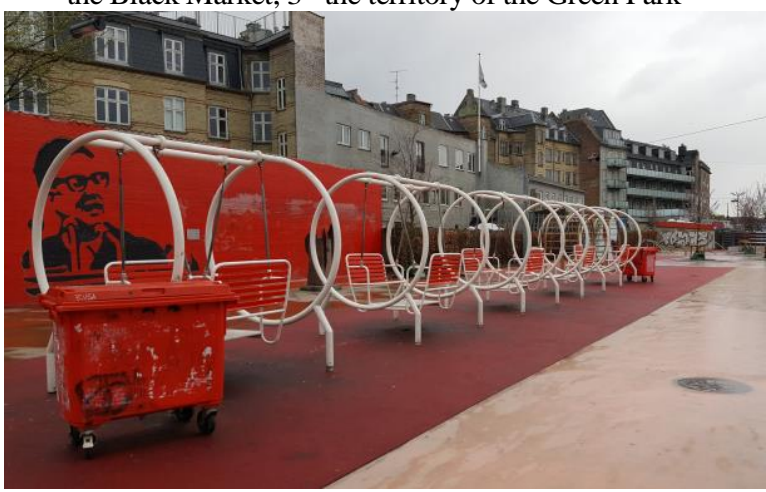

Fig. 5. Objects of the Red Square

[Source: photo by the author, 2017]

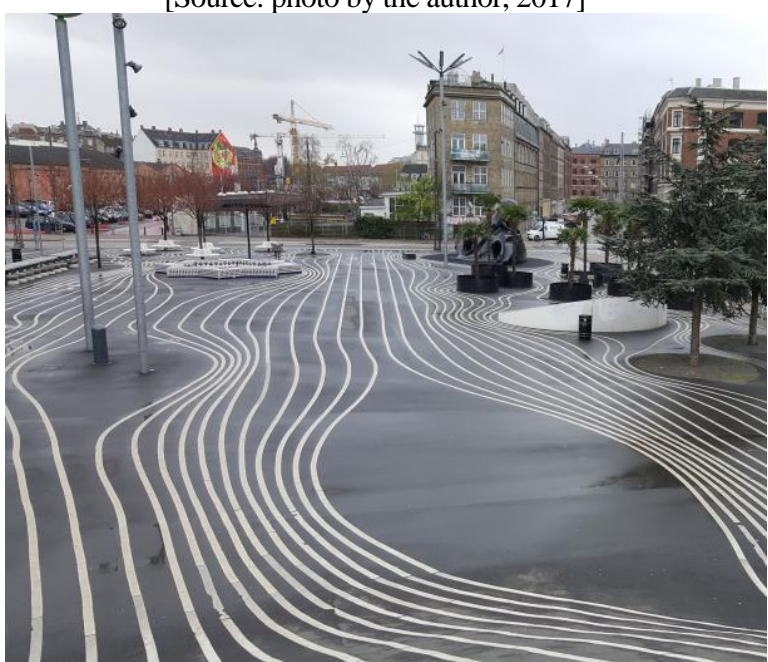

Fig. 6. Objects of the Black Market [Source: photo by the author, 2017]

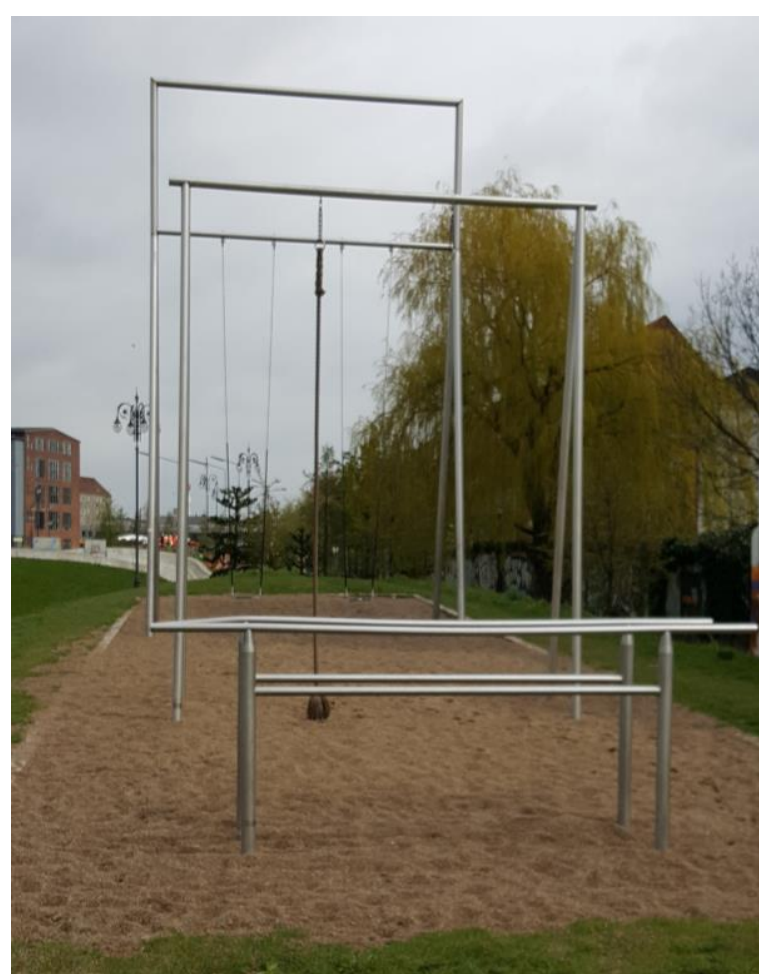

Fig. 7. Objects of the Green Park

[Source: photo by the author, 2017]

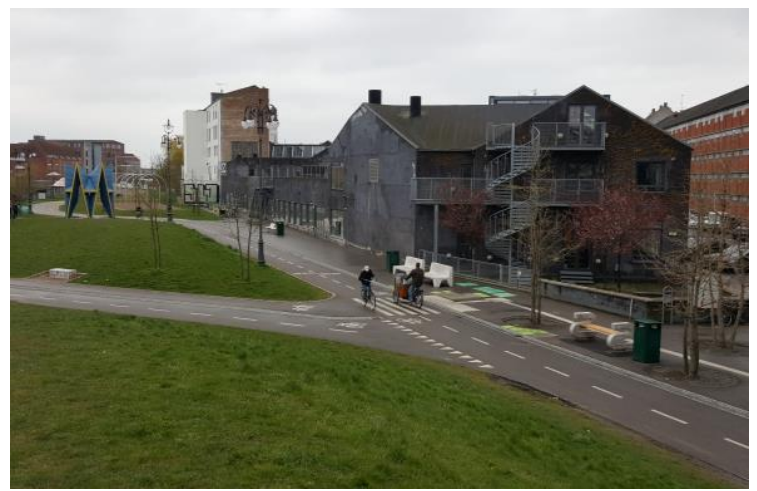

Fig. 8. Bicycle paths in the territory of the Green Park [Source: photo by the author, 2017]

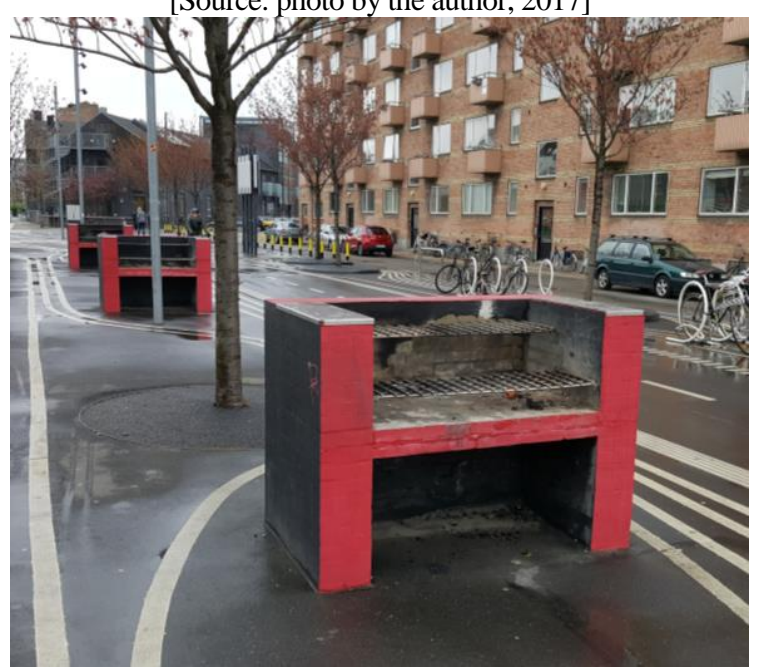

Fig. 9. Picnic places in the public outdoor space [Source: photo by the author, 2017] 


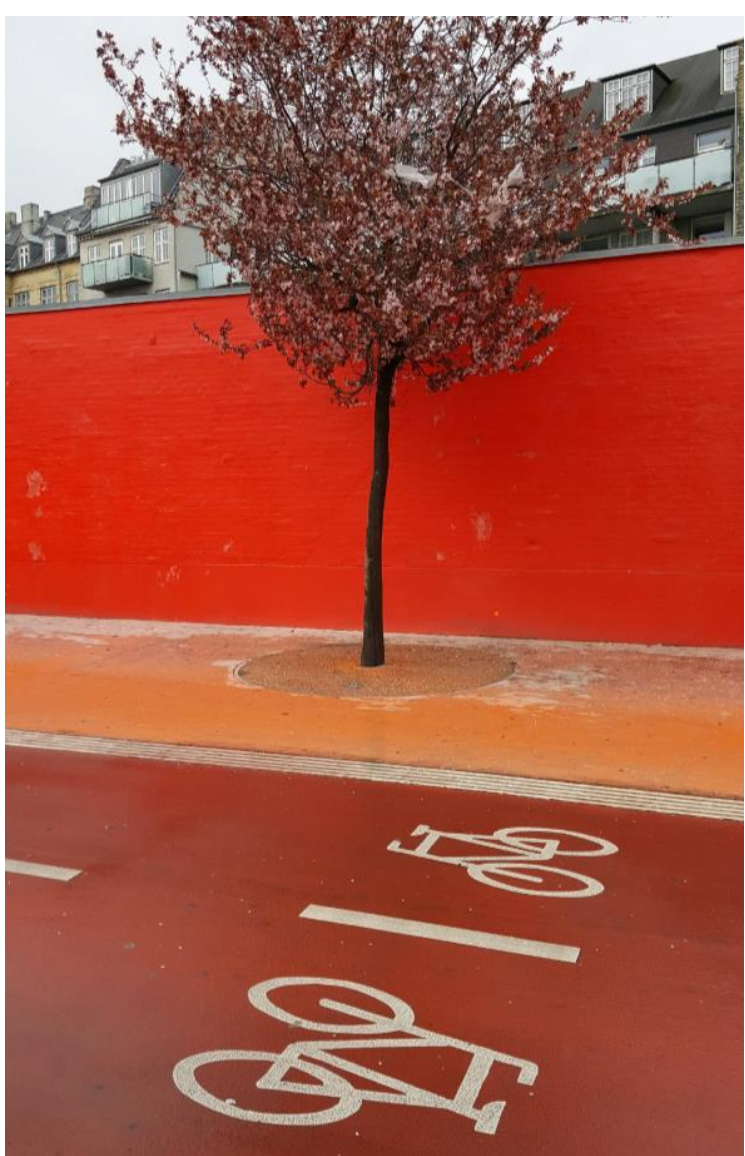

Fig. 10. Contrasting colours of the Red Square

[Source: photo by the author, 2017]

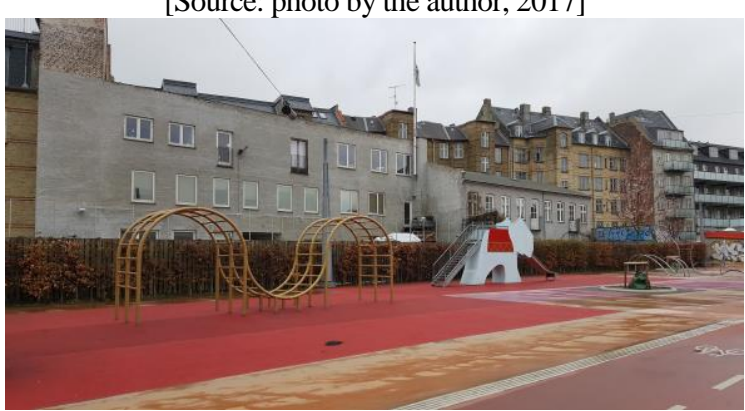

Fig. 11. Attractive objects at the Red Square for different activities

[Source: photo by the author, 2017]

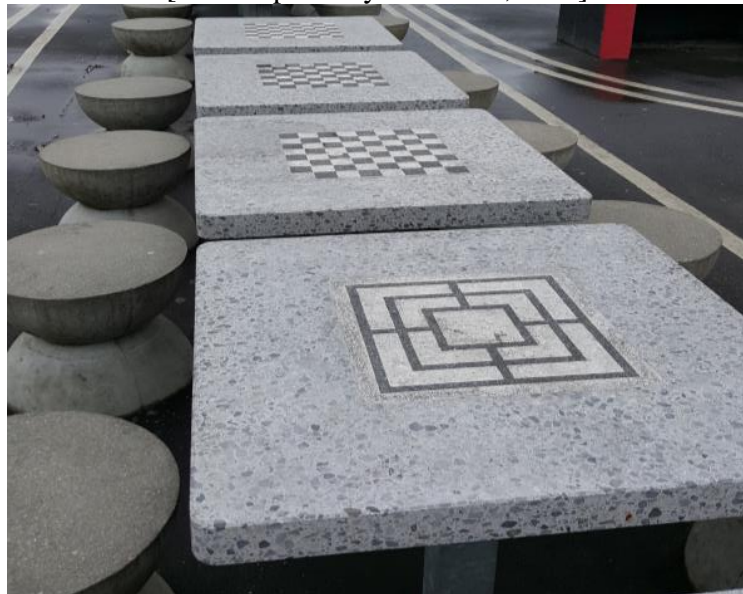

Fig. 12. Chess tables for socializing and recreation in the public outdoor space [Source: photo by the author, 2017]

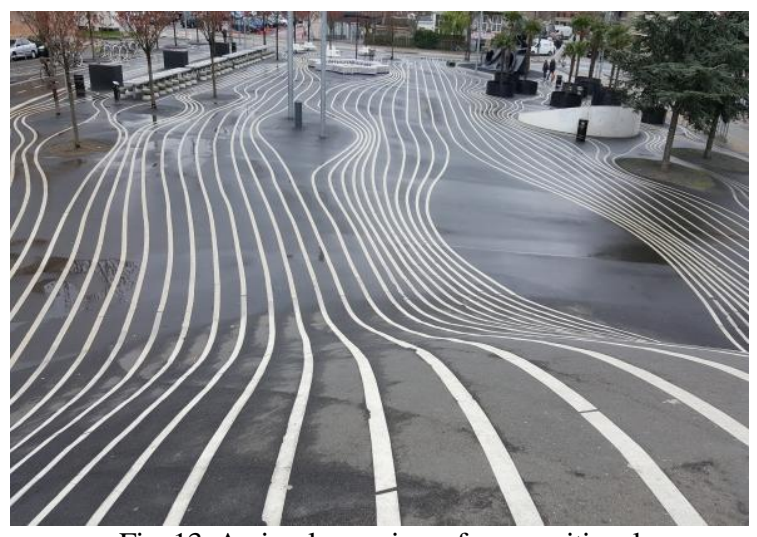

Fig. 13. A visual overview of compositional

harmony for coating [Source: photo by the author, 2017]

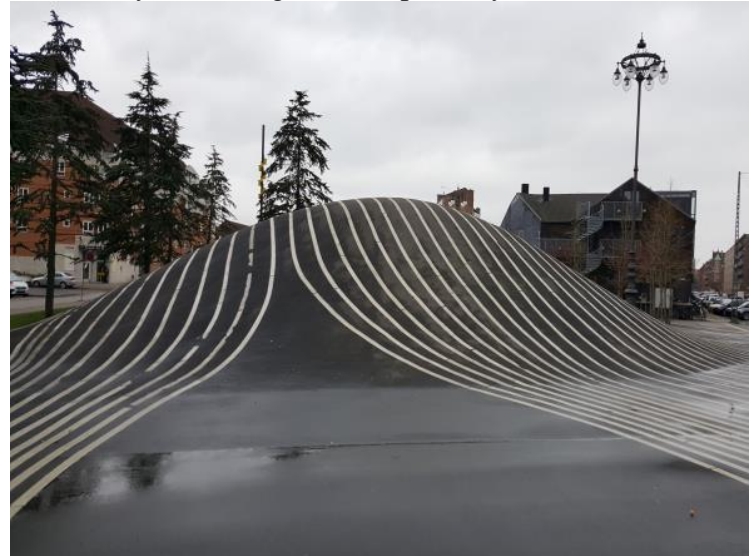

Fig. 14. Elevation - a hill that creates a pleasant touch in the Superkilen Park [Source: photo by the author, 2017]
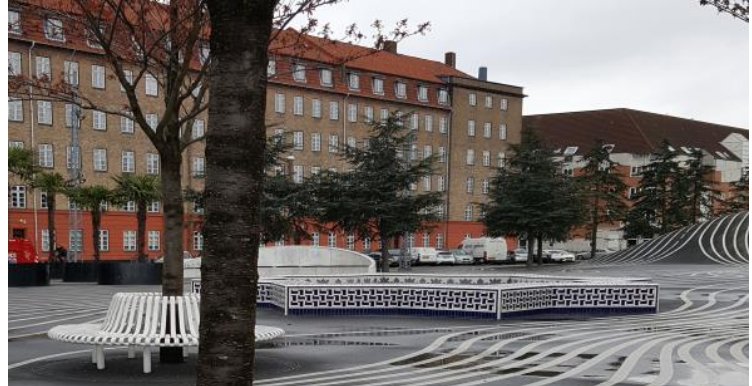

Fig. 15. A blue-tiled water pool, visually associated with warm southern European countries [Source: photo by the author, 2017]

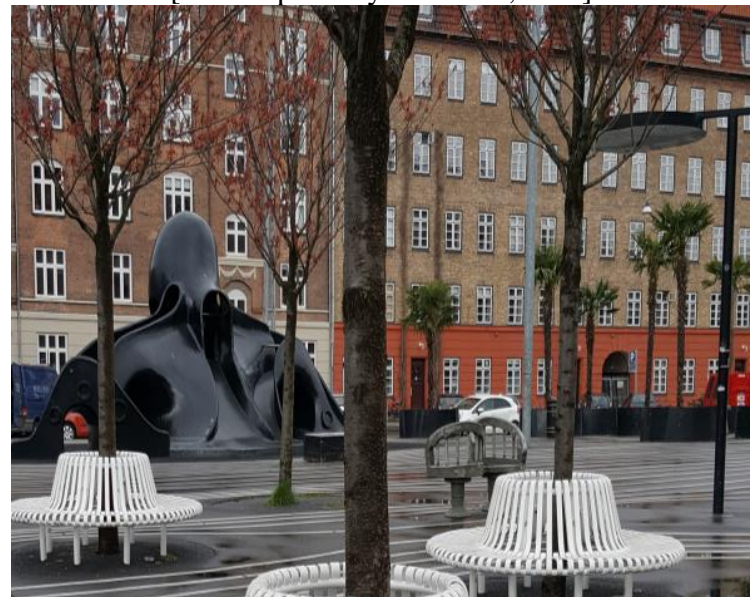

Fig. 16. Use of different species of trees for greenery creating unusual views and accents

[Source: photo by the author, 2017] 
Both hard and synthetic coating features are used in the territory, providing an expressive contrast from the surrounding area. However, The Black Market creates a calm atmosphere, it is part of the park where one can meet other residents and spend time having picnics or playing chess [11], see Figures 12.

A repeating pattern of colours and shapes gives the feeling of order. Repeating lines create harmony [12], see Figures 13 and 14. The white lines on the hard coating create an illusion of movement that visually revitalize this part of the park and leave a completely different impression than from the Red Square. The territory of The Black Market is equipped with various elements of Japanese playgrounds as well as other elements typical of European south that are integrated in this area of Superkilen Park, see Figures 15 and 16. The Green Park is the place where one can have a picnic or walk a dog. There are elevations in the shape of flexible relief, a large lawn and grounds for recreation activities; it is an ideal place where residents can spend their time with families The Green Park's territory contrasts with other parts of the park; there laconic peace and relaxed atmosphere are achieved by means of massive greenery in the urban environment.

\section{Conclusions}

The research gave an evidence that it is possible to create an original design and elements that provide aesthetically beautiful, innovative and attractive recreation place of high quality in urban environment. Careful planning and finding solutions of public outdoor space by means of contrasting, expressive and innovative design elements result in the created place identity of any public outdoor space. Thus Superkilen Park is a positive example that proves the possibility of a different approach to public outdoor space and creates an expressive unity through the use of compositional methods marking new development tendencies in the public outdoor space and landscape architecture on the whole, providing relevant and comfortable public space for each resident of Copenhagen.

\section{References}

1. Treija, S., Bratuškins, U. Development Problems of Large Scale Housing Estates in Riga. Scientific Journal of Riga Technical University: Series 2. Architecture and Urban Planning. Riga: RTU, 2003, Vol. 4, pp. 77-83.

2. Projekts „Ilgtspējīgas lietusūdeṇu apsaimniekošanas sistēmas izveide Latvijas pašvaldībās" (LV2003/005-876/VAPF/0029) ietvaros. Ekonomikas un ekologijas faktori ilgtspējīgai lietusūdeņu apsaimniekošanai apdzīvotās vietās. Jelgava: Jelgavas Tipogrāfija, 2006. 56 lpp.

3. Liepa-Zemeša, M. Topical Dimensional Planning in Cities of Baltic Sea Regiona. Scientific Journal of Riga Technical University: Series 10. Architecture and Urban Planning. Riga: RTU, 2008, Vol. 2, pp. 170-179.

4. Treija, S. Development of Housing Area in Riga. Scientific Journal of Riga Technical University: Series 2. Architecture and Urban Planning. Riga: RTU, 2000, Vol. 1, pp. 58-62.

5. Rīgas pilsētas attīistības perspektīvas starptautiskā kontekstā. Rīgas domes Pilsētas attīistības departaments [online 10.02.2010.]. http://www.rdpad.lv/uploads/rpap/att_plan_izpetes/12_rigas_attistiba_starptautiskaja_konteksta.pdf

6. Biddulph, M. Introduction to Residential Layout. Amsterdam: Elsevier, 2007. 241 p.

7. Gronlund, B. Urban planning for good urban living. Sustainable city of tomorrow. Stockholm: Vasteras, 2005, pp. 31-40.

8. EMBT Arquitectes Associats. Parc de Diagonal Mar. Ultimate Landscape design. New York: Publishing Company, 2005, pp. 33-41

9. Strautmanis, I. Māksla arhitektūrāa. Rīga: Liesma, 1982, 71.-86. lpp.

10. Tisenkopfs, T. Ko nozīmē laba dz̄ive mūsdienu Latvijā? Dzìves kvalitāte Latvijāa . Rīga: Zinātne, 2006, 13.-38. 1pp.

11. Lucchese, J. (10.06.2014.) Superkilen: A Public Space to Feel at Home [online 05.01.2017.] http://landarchs.com/superkilen-public-space-feel-home/

12. Vidlunda, S. Énaugi tavā dārzā. Rīga: Jumava, 2009. 120 lpp.

\section{INFORMATION ABOUT THE AUTHOR:}

Una Īle, Dr. arch., Assist. Prof. (since 2012) at the Faculty of Rural Engineers, Department of Architecture and Construction of the Latvia University of Agriculture, 22 Liela iela, Jelgava, Latvia, LV-3001. E-mail: una.ile@llu.lv

Kopsavilkums. Pētījums balstīts uz autora iepriekš veiktajiem pêtījumiem par ainavisko kvalitāti un mūsdienu attīstības tendencēm, kas veikti pēdējos gados Skandināvijas valstu mērogā, kur caur iegūtajām atzinā̄m un teoriju tika fiksēti daudzveidīgi publiskās ārtelpas kompozicionālie risinājumi gan Norvēgeijā, gan Zviedrijā, kas rezultātā nosaka un iezīmē mūsdien̄̄gu un êrti lietojamu pilsētvides teritoriju ikvienam tās lietotājam. Rakstā atspoguḷotas aktuālās tendences, kā tiek plānota un risināta publiskā ārtelpa, ṇemot par piemēru Kopenhāgenas pilsētas pieredzi un 2012. gadā atklāto Superkilen parku. Pētījumā konstatēts, ka ir iespējams radīt nestandarta dizainu un elementus, kas spēs nodrošināt estētiski kvalitatīvu, inovatîvu un saistošu atpūtas vietu infrastruktūru pilsētvidē. 